\title{
The Model Analysis of The City Identity Towards A Creative City As A Tourism Destination and Its Impact on Customer Based Brand Equity
}

\author{
Ratih Hurriyati \\ Faculty of Economic and Business Education, \\ Indonesia University of Education, \\ Bandung, Indonesia \\ ratih@upi.edu
}

Asep Bayu Nandiyanto

Faculty of Mathematic and Science Education Indonesia University of Education, Indonesia

Bandung, Indonesia

nandiyanto@upi.edu

\author{
Ade Gafar abdullah \\ Faculty of Technology and Vocational Education \\ Indonesia University of Education, Indonesia \\ Bandung, Indonesia \\ Ade_gaffar@upi.edu \\ Isma Widyanti \\ Faculty of Technology and Vocational Education \\ Indonesia University of Education, Indonesia \\ Bandung, Indonesia \\ Isma@upi.edu \\ Ana \\ Faculty of Technology and Vocational Education \\ Indonesia University of Education, Indonesia \\ Bandung, Indonesia \\ Ana@upi.edu
}

\begin{abstract}
Defined Bandung as the Creative Cities Network by the UNESCO (UN) in 2015 in the field of design. Showing the creation of identity of the city as a creative city requires a very large role of all stakeholders, as well as in the context of making a creative city as a tourism destination, which can be characterized typical unique, but its fluctuating number of domestic tourists and overseas indicate a problem that is not optimal rating based brand equity creative city

The purpose of this study was to determine the effect on the city's identity, creative city as a tourism destination, as well as the impact on customer-based brand equity

The size of population was 5,927,421 people and the size of the sample was 390 people. Data source consisted of secondary and primary data. The data collecting techniques consisted of interviews, observations, questionnaires, and literature review. This study utilized
\end{abstract}

Structural Equation Model (SEM) with AMOS program version 21 for IBM.

Results of the study revealed that the implementation of city's identity is good. Bandung as a tourism destination is considered perfect in creativity; and the number of customer based brand equity is high, meaning that Bandung is a good place to revisit. City's Identity gives positive influence on creative city as a tourism destination. A creative city- as a tourism destination contributes positively on the attitude of the tourists. City's Identity has a positive influence on customer based brand equity

Key Word: City Identity, Customer Based Brand Equity, Tourism Destination 


\section{INTRODUCTION}

Determination of Bandung as the Creative Cities Network by the UNESCO (UCCN) in 2015 in the field of design, showing the creation of identity with the city as a creative city requires a very large role of all stakeholders, as well as in the context of making a creative city as a tourism destination, which can be characterized typical unique. Criteria as city design, among others: The industrial design that is well established, cultural landscape, design schools and research centers of design, training groups for designers and creators with sustainable activities, both on a regional and national level, the experience of organizing events dedicated to the design, opportunities for community designers and town planners to use materials of local content, as well as creative industries based on sustainable design. Bandung is a model of a city that managed to develop the potential of the creative economy, create jobs, improve the quality of life and raise the name of Bandung, West Java and Indonesia in the world. This is in line with the history as the city of Bandung, which has a series of recognition as a creative city, including the Creative Cities International Meeting Yokohama in 2007, Bandung was named as one of the cities most creative in East Asia, British Council named Bandung as pilot project cities most creative in East Asia, and in December 2011 the city was named the most creative Bandung in Asia by Channel News Asia of Singapore.

(www.parekraf.go.id).

ComScore Media Matrix Research shows that Bandung is ranked third among other tourism destinations in Indonesia, which is a ranking of the most favorite tourism destinations based research throughout 2013 from the Tripadvisor site. It also can be used as a benchmark city of Bandung in developing tourism to increase tourist arrivals. However, the results of tourists visiting the city of Bandung did not show a significant improvement this can be seen in Table 1 below

Table 1 Number of Travelers Bandung City

\begin{tabular}{llll}
\hline Years & $\begin{array}{l}\text { Foreign } \\
\text { Tourists }\end{array}$ & $\begin{array}{l}\text { Domestic } \\
\text { Tourist }\end{array}$ & All \\
\hline $\mathbf{2 0 0 8}$ & 175.111 & 4.320 .134 & 4.495 .245 \\
$\mathbf{2 0 0 9}$ & 185076 & 4.822 .532 & 5.007 .608 \\
$\mathbf{2 0 1 0}$ & 228.449 & 4.951 .439 & 5.179 .888 \\
$\mathbf{2 0 1 1}$ & 225.585 & 6.487 .239 & 6.712 .824 \\
$\mathbf{2 0 1 2}$ & 176.855 & 5.080 .584 & 5.257 .439 \\
$\mathbf{2 0 1 3}$ & 176.432 & 5.388 .292 & 5.564 .724 \\
\hline $\mathbf{2 0 1 4}$ & 180.143 & 5.627 .421 & 5.807 .564 \\
\hline S0urces & $:$ &
\end{tabular}

Sources : Department of Culture and Tourism Bandung, 2015.
Characteristics of the city that has had many results of creative industries are an asset in creating a creative city.. Through the creation and innovation, Bandung, formerly known as the attractiveness of the city atmosphere began to turn into a tourist destination that is known by a variety of creativity. It should invite tourists to visit the city of Bandung and enjoy a variety of creative industry's results. Creation of a creative city as a tourism destination requires a very large role of all stakeholders. This time the central government has given full support to the establishment of Bandung as a creative city, and in line with the process, local government and other stakeholders in the city of Bandung are constantly working to make it happen.. In the context of making the creative city as attraction tourism destinations, tourists are also able to play an active role through collaboration among business entrepreneurs travel with tourists, so it can produce a variety of productive product innovations that can improve the value of the experience rating..

Based on these conditions, the identity with the city can serve as a model that dynamically through creative activity among business entrepreneurs travel to the rating of the creative city as a tourism destination, where it is carried out to explore from the perspective of tourists, as well as the further consideration to the impact upon the customer based brand equity for tourism destination. As for the purpose of this study, to determine the effect on the city's identity creative city as a tourism destination, as well as its impact on customer based brand equity-tourism destination

\section{a. City Identity}

\section{LITERATUR RIVIEW}

City identity is formed by elements of that city by the community is very impressive, some elements within the city, such as roads, urban areas, centers (lynsch 1960) . Society's view of an element within the city will have a special meaning for themselves. (stokol and shumaker, 1981, steadman 2002), The association will trigger their view that such elements of the identity of the city. Aaker (2002) states, differences between products and brands can be used as a guide to clarify the identity. Products include the scope, attributes, quality, and use. While brands include symbols, brand personality, all the associations for the organization, country of origin, imaging by the user, the benefits of self-expression, emotional benefits, and the relationship between brands and customers.

Brand also plays an important role in a City. With the city attributes that correspond to good management. The establishment of Brand Identity will be easier to do. Tourists will also get to know the identity of the city so 
that the city of Bandung in this case it was getting a special position in the minds of tourists. David A. Aaker and Erich (2002: 43) brand identity are made up of twenty dimensions are merged into four, namely brand as product, brand as organization, brand as a person, and brand as a symbol

\section{b. Tourism Destinations}

Act No. 10 of 2009 on Tourism state that, in tourism destinations hereinafter referred to as the tourism destination is the geographic regions that are within one or more administrative regions in which there are a tourist attraction, public facilities, tourism facilities, accessibility, and community interrelated and complementary realization of tourism. According to Holloway and Humphreys (2012), can be a destination resort or cities, regions within countries, across the country or even a larger area.

According to Buhalis (2000), tourism, destinations are a mix of tourism products, which offers an integrated experience to travelers. In general, destinations are defined as the country, an island or city. Tourism destination designed to meet the needs of tourists

\begin{tabular}{|c|c|c|}
\hline \multicolumn{3}{|c|}{$\begin{array}{c}\text { Six As Framework for The Analysis of } \\
\text { Tourism Destinations }\end{array}$} \\
\hline $\begin{array}{l}\text { Attractions } \\
\text { - Natural } \\
\text { - Man-made } \\
\text { - Artificial } \\
\text { - Purpose } \\
\text { built } \\
\text { - Heritage } \\
\text { - Special } \\
\text { events }\end{array}$ & $\begin{array}{l}\text { Accessibil } \\
\text { ity } \\
\text { - Entire } \\
\text { transport } \\
\text { ation } \\
\text { - System } \\
\text { comprisi } \\
\text { ng of } \\
\text { routes } \\
\text { - Terminal } \\
\text { s }\end{array}$ & 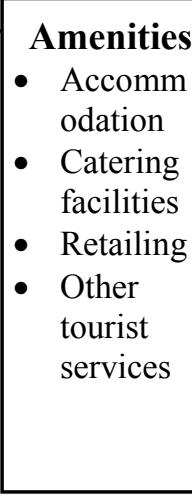 \\
\hline $\begin{array}{l}\text { Available } \\
\text { packages } \\
\text { - Pre } \\
\text { arranged } \\
\text { packages } \\
\text { by } \\
\text { intermedi } \\
\text { aries }\end{array}$ & $\begin{array}{l}\text { Activities } \\
\text { - All } \\
\text { activities } \\
\text { available } \\
\text { at the } \\
\text { destinati } \\
\text { on and } \\
\text { what } \\
\text { consume } \\
\text { rs will } \\
\text { do } \\
\text { during } \\
\text { their } \\
\text { visit }\end{array}$ & $\begin{array}{c}\text { Ancillary } \\
\text { services } \\
\text { - } \quad \text { Services } \\
\text { used by } \\
\text { tourists } \\
\text { such as } \\
\text { banks, } \\
\text { telecom } \\
\text { municati } \\
\text { ons, etc. }\end{array}$ \\
\hline
\end{tabular}

In the context of a creative city, Bandung designated by UNESCO as a city of creative design, meaning the city of Bandung to be a trend setter in the creativity of design creation. However, the research results from Hurriyati, Sofwan (2015), rating assesses Bandung rated fits the category as a creative city-based crafts and folk art, as well as based gastronomic.

Excavation of these categories can be one input from the government, as well as other relevant parties to support the city of Bandung as the creative design. Predicate creative city can be used as one way of promoting the city of Bandung as a tourism destination characterized so as to reveal the identity of the city of Bandung as a city of design or in other words, the brand identity of the city or the city of Bandung as a creative city design.

\subsection{Customer based Brand Equity for Tourism Destination}

Keller (2001) states that in establishing the brand of the city or in this case a strong city brand, two common questions: (1) What makes a brand the strong town? (2) How do you build a strong city brand?

To help answer these questions, then developed a model for brand building model called Customer-Based Brand Equity CBBE- Tourism Destination. The basic premise of this model is that the city brand strength lies in what travelers have learned, taste, see, and hear about the brand of the city from time to time. In other words, the strength of the brand the city are in the minds of tourists. The challenge for cities in building a strong brand is to make sure that travelers have the right kind of experience with the products and services of the city, as well as the accompanying marketing program so that unwanted thoughts, feelings, images, beliefs, perceptions, opinions, became associated with the city's identity

(Keller 2013)Customer-based brand equity as the differential effect that brand knowledge has on consumer response to the marketing of that brand. A brand has positive customer-based brand equity when consumers react more favorably to a product and the way it is marketed when the brand is identified than when it is not (say, when the product is attributed to a fictitious name or is unnamed). Thus, customers might be more accepting of a new brand extension for a brand with positive customer-based brand equity, less sensitive to price increases and withdrawal of advertising support, or more willing to seek the brand in a new distribution channel. On the other hand, a brand 
has negative customer-based brand equity if consumers react less favorably to marketing activity for the brand compared with an unnamed or fictitiously named version of the product

Eunyoung Jung Jae Hee and Sung (2008: 26) mentions that customer-based brand equity has four elements, namely.: (a) Brand Loyalty (b)Brand Awareness (c) Perceived quality (d) Brand Association

While Keller (2001, 2013: 107) states that building a strong brand, based on the customer-based brand equity model, consisting of a sequence of steps, where each step depends on the success in completing the previous step. All steps involve the achievement of certain goals with customers, both existing customers and potential. The first step is to ensure the identification with the brand with customers and brand association in the minds of customers with specific product or class of customer needs. The second step is to firmly establish the significance / meaning to the brand in the minds of customers with a number of brand associations linking strategic, tangible and intangible. The third step is to obtain customer responses appropriate to the brand identity and brand meaning. The fourth and final step is to convert the brand to create the intensity of the response, an active relationship between customer loyalty and brand.

The four steps are a set of fundamental questions that customers are always wondering about the brand-at least implicitly. Four questions in accordance with the steps the brand is.

:

1. Who are you? (brand identity)

2. What are you? (brand meaning)

3. What about you? What do I think or feel about you? (brand responses)

4. What about you and me? What kind of association and how much of a connection would I like to have with you? (brand relationships) (Keller (2013:107)

After four steps, in turn, involves six brand-building block that is brand salience, brand performance, brand imagery, brand judgments, feeling's brand, and brand resonance. The most valuable brand-building block, brand resonance, occurs when all blocks have been assigned to build other brands. . Through true brand resonance, customers express high levels of brand loyalty, so they are actively looking for ways to interact with the brand and share their experiences with others. Companies are able to achieve brand resonance reap a number of benefits, such as greater premium prices and marketing programs more efficiently and effectively,.. The followings are hypotheses in this research:
- H1: City Identity influences creative city as a tourism destination.

- H2: Creative City as a tourism destination influences customer based brand equity

- H3: City Identity influences customer based brand equity

- H4: City Identity influences creative city as a tourism destination as well as its impact CBBE.

\section{METHOD}

This research employs quantitative method. According to Maholtra (2014: 7), quantitative method called positivistic methods because it is based on the philosophy of positivism. The population in this study is the tourists who visit Bandung. The number of tourists who visit Bandung in 2014 is 5,627,421 (Source: Bandung Office of Culture and Tourism, 2015). This study uses the formula slovin sampling. The number of samples in this study is 390 people. Sampling technique in this study is the probability sampling. The population in this study is moving population. Therefore, the sampling technique in this study utilizes random sampling technique. Data collection techniques in this study employ the technique of interview, observation, questionnaires, and literature studies. This research also employs descriptive and verification method. Data descriptive analysis is the picture of data from the data collection that is used to enrich the discussion. An overview of respondent reaction data enables us to see how respondents respond to each of the studied variables: the co-creation experience, tourism destinations, and revisit intention. To interpret these variables easier, categorization on respondent score is conducted.The scale of measurement in this study generally uses alternative answers, i.e. (5) very good, (4) good, (3) quite good, (2) not good, and (1) very not good. The data obtained can be known based on the scores of data recapitulation. Values are compared to the standard scoring criteria obtained through the calculation of the criterion score and smallest score. Therefore, the standard score reveals continuum area that shows the ideal region (Maholtra: 2009). Verification analyzes performed in this study uses structural equation modelling (SEM) analysis techniques with AMOS version 21 program for analysing the causal relationships between variables 


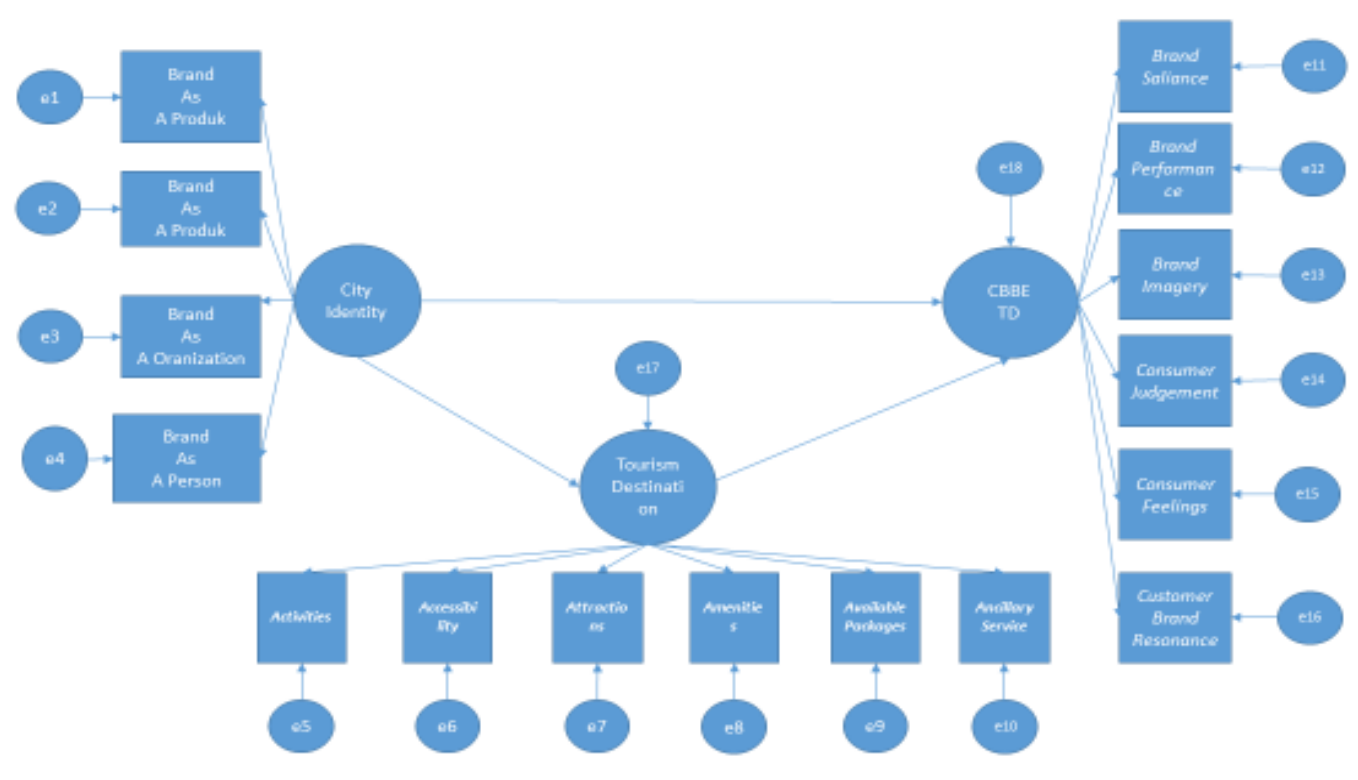

Figure. 1 Structural Equetional Model

\section{RESULT AND DISCUSSION}

\subsection{Result Descriptive Analysis \\ 1. Variable of City Identity}

Through the calculation of the total score of the City Identity variable, it can be seen that the respondents are considered in the category of "High". This shows that the model City Identity has been well perceived by tourists who visit Bandung, through various aspects that are measured in dimensions of City Identity : brand as product, brand as organization, brand as a person, and brand as a symbol. Aaker (2002) suggest that the city should focus on the dimensions of choice of their interactions with customers to shape up the city Identity well.

\section{Tourism Destinations Variable}

Through the calculation of the total score of tourism destinations variable, it can be seen that the respondents are considered in the category of "Quite Good". This shows that the tourism destinations in Bandung are viewed as good by tourists, through various aspects that are measured in the dimensions of tourism destinations: attractions, accessibility, amenities, activities, packages available, and ancillary service. The six dimensions must be able to meet the needs of tourists with good. Buhalis (2000) suggests that tourism destinations are a mix of tourism products that offer an integrated experience to tourist. Tourism destinations designed to meet the needs of tourists.

\section{Costumer Based Brand Equity}

Through the calculation of the total score of Customer based Brand equity variable, it can be seen that the respondents are considered in the category of "High" The value describes the majority of travelers found customer-based brand equity Bandung high. This means that Bandung has a high brand strength in the eyes of tourists after they see, hear, learn, think and feel the direct product of Bandung city services. Strong brands have high brand equity. Brand equity is a positive differential effect that if customers know the brand name, the customer will respond to a product or service. One measure of brand equity is the extent to which customers are willing to pay more for the brand.(Kotler \& Armstrong, 2015)

Customer-based brand equity is owned by differential effect of brand knowledge on consumer response to marketing the brand. A brand has a customer-based brand equity is positive when consumers react more positively to the product and how the product is marketed as a brand was identified, compared to when the brand was not identified. Brand has a customer-based brand equity is negative if consumers do not like the marketing activities for the brand in the same state. (Kotler \& Keller, 2016)

The basic premise of the customer-based brand equity model is that the strength of the brand lies in what customers have learned, taste, see, and hear about the brand over time. In other words, the strengths of the brand are in the customer's mind. (Keller, 2001). 
(cut of value), it shows that the a whole conceptual structural equation models were designed based on goodness of fit meet the eligibility model (fit), which means in accordance with the conditions of empirical purchasing behavior through the processing results of SEM analysis AMOS 22 are presented in the following figure 4.2.

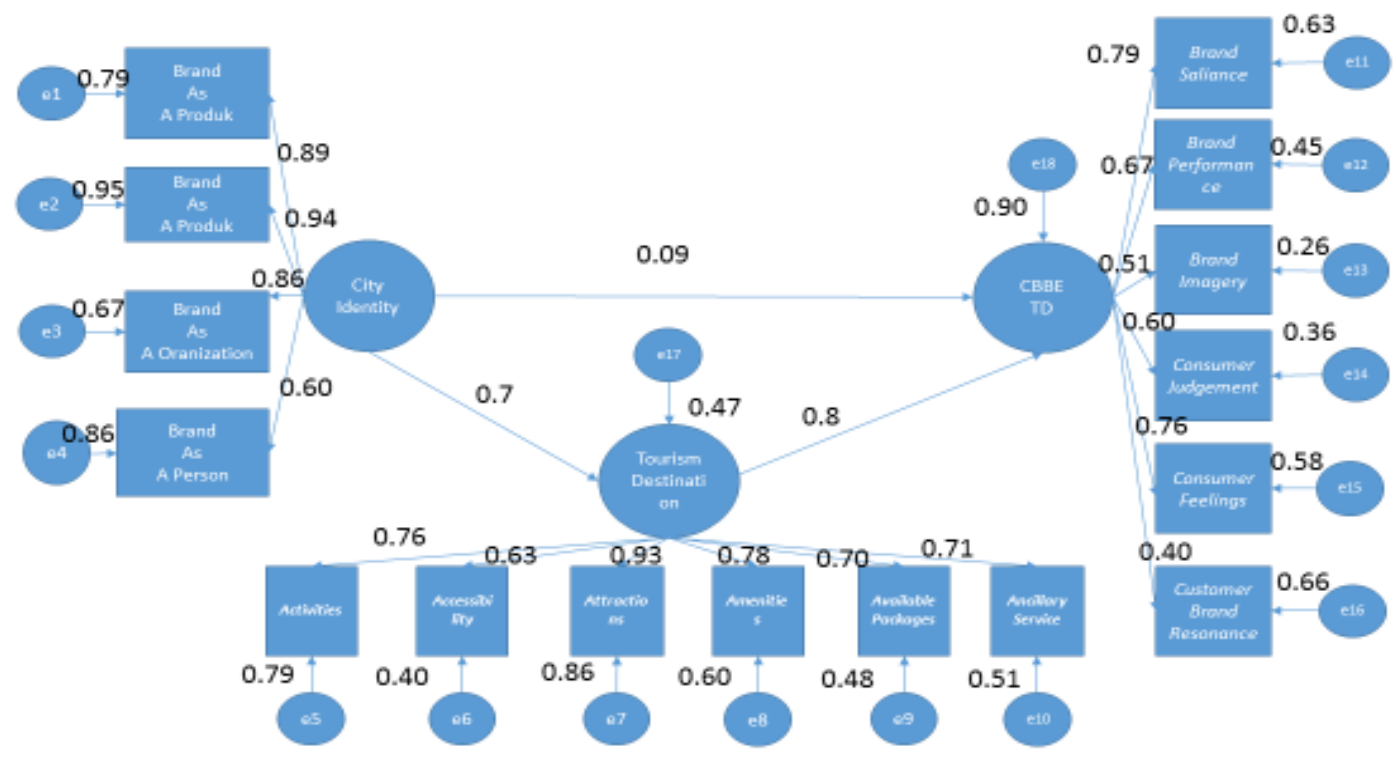

Figure 4.1. . Structure Model Analysis

Based on the figure In order to find the decisionmaking, the hypothesis testing is done by comparing the amount of p-value (Santoso, 2014). The level of significant is on a confidence level of $95 \%$.

1 . If the p-value $\geq 0.05$, the null hypothesis ( $\mathrm{H} 0)$ is accepted, meaning that there is no influence between the two variables statistically.

2 . If the p-value $\leq 0.05$, the null hypothesis ( $\mathrm{H} 0)$ is rejected, meaning that there is influence between the two variables statistically

\section{Table 4,1}

Results of Hypothesis
Table 4.2.

Results Effect of Total

\begin{tabular}{l|l|l|}
\multicolumn{1}{c|}{ Variabel } & Koefisien $\boldsymbol{\beta}$ & \multicolumn{1}{c|}{ Ket } \\
\hline $\begin{array}{l}\text { City Identity } \rightarrow \\
\text { Tourism Destinatiom }\end{array}$ & 0,70 & Pengaruh langsung \\
\hline $\begin{array}{l}\text { Tourism Destinatiomn } \\
\rightarrow \text { CBBE-TD }\end{array}$ & 0,881 & Pengaruh langsung \\
\hline $\begin{array}{l}\text { City Identity } \rightarrow \text { CBBE- } \\
\text { TD }\end{array}$ & 0,090 & Pengaruh langsung \\
\hline $\begin{array}{l}\text { City Identity } \rightarrow \text { CBBE- } \\
\text { TD }\end{array}$ & 0,619 & $\begin{array}{l}\text { Pengaruh tdk } \\
\text { langsung }\end{array}$ \\
\hline
\end{tabular}

\begin{tabular}{|c|c|c|c|}
\hline \multicolumn{2}{|r|}{ Hyphothesis } & Koefisien $\beta$ & p- \\
\hline H1 & $\begin{array}{l}\text { City Identity } \rightarrow \text { Tourism } \\
\text { Destination }\end{array}$ & 0.70 & 0,000 \\
\hline H2 & $\begin{array}{l}\text { Tourism Destinatiom } \rightarrow \\
\text { CBBE }\end{array}$ & 0,881 & 0,000 \\
\hline H3 & City Identity $\rightarrow$ CBBE & 0,090 & 0,042 \\
\hline H4 & $\begin{array}{l}\text { City Identity } \rightarrow \text { Tourism } \\
\text { Destination } \rightarrow \text { CBBE }\end{array}$ & 0,838 & 0,000 \\
\hline
\end{tabular}

\subsection{Discussion} Hipotesis 1

Hypothesis 1: City Identity (CI ) influences the creative city as a tourism destination (TD). H0: There is no significant influence of City Identity to the creative city as a tourism destination. H1: There is a significant influence of City Identity to the creative city as a tourism destination.

Result of hypotheses testing on the table shows that the $p$-value is 0.000 . It shows that the value is smaller than 0.05 , so that $\mathrm{H} 0$ is rejected and $\mathrm{H} 1$ is accepted. 
It can be stated that there is a significant relationship between the city Identity and tourism destinations. The magnitude of the effect is positive of 0.7 and in the interpretation, the size is considered strong. As a result, it can be said that the higher city identity value means the higher the influence on tourism destinations in Bandung.

Results of this study strengthen the results of previous research conducted by Jager (2009) which suggests that tourism organizations or businesses should be able to interact with tourists through innovative and dynamic manners. Tourism performers should concentrate on city identity to create innovation to improve the competitiveness of tourism destinations. Aaker (2002) suggest that the city should focus on the dimensions of choice of their interactions with customers to shape up the city Identity well.

\section{Hypothesis 2}

Hypothesis 2: Creative City as a tourism destination (TD) influences Customer Based Brand Equity (CBBE).

H0: There is no significant influence of the creative city as a tourism destination to Customer Based Brand Equity

H1: There is a significant influence of the creative city as a tourism destination to Customer Based Brand Equity.

Result of hypotheses testing on the table shows that the $p$-value is 0.000 . It shows that the value is smaller than 0.05 , so that $\mathrm{H} 0$ is rejected and $\mathrm{H} 1$ is accepted. It can be stated that there is a significant relationship between tourism destinations and revisit intention. The magnitude of the effect is positive of 0.881 and in the interpretation, the size is considered very strong. As a result, it can be said that the higher value and character of tourism destinations means the higher the influence on Customer Based Brand Equity in Bandung.

Results of this study strengthen the results of previous research conducted by Keller 2001The basic premise of the customer-based brand equity model is that the strength of the brand lies in what customers have learned, taste, see, and hear about the brand over time. In other words, the strengths of the brand are in the customer's mind.

\section{Hypothesis 3}

Hypothesis 3: City Identity (CI) influences Customer Based Brand Equity (CBBE).

H0: There is no significant influence of the City Identity to. Customer Based Brand Equity

H1: There is a significant influence of the City Identity to Customer Based Brand Equity .
Result of hypotheses testing on the table shows that the $p$-value is 0.042 . It shows that the value is smaller than 0.05 , so that $\mathrm{H} 0$ is rejected and $\mathrm{H} 1$ is accepted. It can be stated that there is a significant relationship between the City Identity and the Customer Based Brand Equity . The magnitude of the direct effect is 0.090 and in the interpretation is considered very low. The magnitude of the indirect effect is 0.619 and in the interpretation is considered strong. It demonstrates that the model of city Identity is an interactive experience between tourists and providers of tourist products, where tourism destinations as a collection of tourist products are the object of the activities of city identity. Therefore, there is a strong indirect relationship between the city identity and customer based brand equity.

Results of this study strengthen the results of previous research conducted by Nurhanan, et al (2013) which suggests that there is correlation between company as service provider and consumers as users of services in the tourism industry to create a city Identity . City Identity has been considered as a way to create values. Additionally, it enables customers to reconstitute the intention to visit based on their objectives and needs of tourism..

\section{Hypothesis 4}

Hypothesis 4: City Identyty (CI) influences on creative city as a tourism destination (TD), and affects Customer Based Brand Equity (CBBE).

$\mathrm{H} 0$ : There is no significant effect of city Identity to the creative city as a tourism destinations and has no impact on Customer Based Brand Equity .

H1: There is a significant effect of City Identity to the creative city as a tourism destination and has an impact on Customer Based Brand Equity ..

Result of hypotheses testing on the table shows that the $\mathrm{p}$-value is 0.000 . It shows that the value is smaller than 0.05 , so that $\mathrm{H} 0$ is rejected and $\mathrm{H} 1$ is accepted. It can be stated that there is significant relationship between the co-creation experience and the creative city as a tourism destination and it affects the revisit intention. The coefficient of determination (R2) which is the amount of influence value of co-creation experience to the creative city as a tourism destination as well as the intention revisit is equal to $0.838(\mathrm{R} 2=0.912)$. In the interpretation, the effect size is considered very strong. Therefore, it can be said that the higher City Identity value means the higher tourism destinations value and character, as well as the higher influence on Customer Based Brand Equity to Bandung

\section{CONCLUTION}

The research that has been done through descriptive analysis and verification by using analysis of 
structural equation modeling (SEM) concludes the following points.

1. City Identity perceived by the respondents is considered good. The highest assessment score by the respondents, based on the score of the dimensions of City Identity, is brand it's a persons.

2. Bandung tourism destinations are rated quite well by tourists who visit the city of Bandung. The highest assessment score by the respondents, based on the dimensions of the tourism destination is the attraction.

3. Revisit intention of domestic tourists to the city of Bandung is considered good. The highest assessment score by the respondents, based on the dimensions of the $\mathrm{CBBE}$, is the Brand Performance.

4. There is a high impact of city identity to the creative city as a tourism destination. Subsequently, it can be said that the increasing adoption of city identity model will influence tourism destinations in the city of Bandung.

5. There is a very high influence of the creative city as a tourism destination toCBBE. So it can be said that the higher the value and character of tourism destination, then the higher the interest of tourists to come back to the city of Bandung.

6. There is a very low direct effect and high indirect effect of City Identity to CBBE. It shows that the city Identity is an interactive experience between tourists and providers of tourist products. Tourism destinations, as a collection of tourist products, are the object of the city identity activities. Hence, there is a high indirect effect of City Identity to CBBE.

7. There is a very high influence of city identity to the creative city as a tourism destination, as well as its impact on CBBE. It shows that involvement or interaction between tourists with the product/tourism activity providers affects various tourism products incorporated in a tourism destination, as well as the conditions and characteristics that affects tourism destination to revisit the city of Bandung.

\section{REFERENCE}

[1] Alma, Buchari. 2013. Manajemen Pemasaran dan Pemasaran Jasa. Bandung: Alfabeta.

[2] Aaker 2014. Aaker On Branding ; 20 Principle that Drive Sucsess . Jakarta: PT Rineka Cipta.

[3] Baker, Dwayne; Crompton, John. 2000. Quality, Satisfaction and Behavioral Intentions. Annals of Tourism Research. Vol 27.
[4] Buhalis, Dimitrios. 2000. Marketing The Competitive Destination Of The Future. Journal of Tourism Management. Vol 21.

[5] Bunnag, T. (2014). Volatility analysis of international tourist arrival growth rates to Thailand using Garch and GJR model, Journal of Environmental Management and Tourism, (Volume V, Summer), 1(9): 70-83. doi:10.14505/jemt.v5.1(9).06. Available from: http://www.asers.eu/ journals/jemt/curent-issue.

[6] Chang, Lan-lan. 2013. Influencing Factors On Creative Tourists' Revisiting Intentions: The Roles Of Motivation, Experience And Perceived Value. Clemson University.

[7] Hair, Black. 2010. Multivariate Analysis.10th Edition. Pearson Education.

[8] Holloway; Humphreys. 2012. The Business of Tourism. England: Pearson.

[9] Hsieh dan Lug. 2013. Reconstructing Revisit Intention Scale in Tourism. Journal of Applied Sciences.

[10] Instruksi Presiden Nomor 6 Tahun 2009 tentang Pengembangan Ekonomi Kreatif.

[11] Jager, Koert. 2009. Co-Creation as a Strategic Element of Tourism Destination Competitiveness.

[12\} Joynathsing, Chavi. 2010. Understanding The Behavioral Intention of European Tourist. International Research Symposium in Service Management.

[13] Kotler, Philip; Kevin Lane Keller. 2016. Marketing Management. Prentice Hall.

[14] Kotler, Philip; Bowen, John; Makens, James. 2010. Marketing for Hospitality and Tourism. England: Pearson.

[15] Lee, Jinsoo. 2009. Cognitive Destination Image, Destination Personality and Behavioral Intention: An Integrated Perspective of Destination Branding. Research Article The Hongkong Polytechnic University and Temple University.

[16] Lee, Monkyu; Lawrance, Cunningham. 2001. A Cost/Benefit Approach to Understanding Service Quality. Journal of Service Marketing.

[17] Moelyono, Mauled. 2010. Menggerakan Ekonomi Kreatif. Jakarta: Rajagrafindo Persada.

[18\} Morrison, Alastair. 2013. Marketing and Managing Tourism Destination. New York: Routledge.

[19 Morrison, Alastair. 2010. Hospitality and Travel Marketing. Clifton Park, New York: Cengage.

[20] Oliveira, E.(2013). Digital complexity in destination branding: a preliminaryanalysis to destination Portugal, Journal of Environmental Management and Tourism, (Volume IV, Winter), 2(8):65-76. doi:10.14505/jemt.v4.2(8).02. Available from: http://www.asers.eu/ journals/jemt/curent-issue 
[21] Directorate of Tourism Investment Destination Planning - Ministry of Tourism and Creative Economy. 2013. Creative Zone Development. Jakarta.

[22] Pitana; Diarta. 2009. Pengantar Ilmu Pariwisata. Yogyakarta: Andi.

[23] Prahalad and Ramaswany. 2004. Co-creation Experience: The Next Practice in Value Creation.

[24] Ramadlani; Hadiwidjaja. 2013. Determinants of Tourist Revisit Intention to Kota Batu. University of Brawijaya.

[25] Ratih Hurriyati , Dara Myrna Sofwan 2015. Analisys of Co-creation Experience towards a Creative City as a Toursim Distination and its Impact on Revisting Intention Journal of Environmental Management and Tourism, Desember ISSN: 20687729 Indexing Scopus ASERS Publisher

[26] Rencana Pembangunan Jangka Menengah Daerah (RPJMD) Kota Bandung Tahun 2014 - 2028.

[27] Santoso, Singgih. 2014. Konsep Dasar dan Aplikasi SEM dengan AMOS 22. Jakarta: PT Elex Media Komputindo.

[28] Schebal, Ctirad. 2011. Evaluation Of Tourist Destination Attractivness.

[29] Suryana. 2013. Ekonomi Kreatif. Jakarta: Salemba.

[30\} Undang-Undang Republik Indonesia Nomor 10 Tahun 2009 tentang Kepariwisataan.

[31\} Tsai, Wen Chia. 2012. A Study of Consumer Behavioral Intention to Use E-books: The Technology Acceptance Model Perspetive. Innovative Marketing Vol 8. 